\title{
Citric Acid as a Set Retarder for Calcium Aluminate Phosphate Cements
}

\author{
T. Sugama \\ L.E. Brothers \\ Halliburton \\ 2600 S. $2^{\text {nd }}$ Street \\ Duncan, OK 73536-0442, USA
}

January 2005

\section{Energy Sciences and Technology Department} Energy Resources Division

\author{
Brookhaven National Laboratory \\ P.O. Box 5000 \\ Upton, NY 11973-5000 \\ www.bnl.gov \\ Managed by \\ Brookhaven Science Associates, LLC
}

This program report, issued by Raymond LaSala (Program Manager, DOE Office of Geothermal Technologies) was performed under the auspices of the U.S. Department of Energy, Washington, D.C. under Contract No. DE-AC02-98CH10866 


\section{DISCLAIMER}

This report was prepared as an account of work sponsored by an agency of the United States Government. Neither the United States Government nor any agency thereof, nor any of their employees, nor any of their contractors, subcontractors, or their employees, makes any warranty, express or implied, or assumes any legal liability or responsibility for the accuracy, completeness, or any third party's use or the results of such use of any information, apparatus, product, or process disclosed, or represents that its use would not infringe privately owned rights. Reference herein to any specific commercial product, process, or service by trade name, trademark, manufacturer, or otherwise, does not necessarily constitute or imply its endorsement, recommendation, or favoring by the United States Government or any agency thereof or its contractors or subcontractors. The views and opinions of authors expressed herein do not necessarily state or reflect those of the United States Government or any agency thereof. 


\begin{abstract}
Citric acid added as set retarder significantly contributed to enhancing the setting temperature and to extending the thickening time of a calcium aluminate phosphate (CaP) geothermal cement slurry consisting of calcium aluminate cement (CAC) as the base reactant and sodium polyphosphate $(\mathrm{NaP})$ solution as the acid reactant. The set-retarding activity of citric acid was due to the uptake of $\mathrm{Ca}^{2+}$ ions from the CAC by carboxylic acid groups within the citric acid. This uptake led to the precipitation of a Ca-complexed carboxylate compound as a set-retarding barrier layer on the CAC grains' surfaces. However, this barrier layer was vulnerable to disintegration by the attack of free $\mathrm{Ca}^{2+}$ ions from $\mathrm{CAC}$, and also to degradation at elevated temperature, thereby promoting the generation of exothermic energy from acid-base reactions between the CAC and NaP after the barrier was broken. The exothermic reaction energy that was promoted in this way minimized the loss in strength of the citric acid-retarded cement. The phase composition assembled in both retarded and non-retarded cements after autoclaving at $180^{\circ} \mathrm{C}$ encompassed three reaction products, hydroxyapatite (HOAp), hydrogrossular and boehmite, which are responsible for strengthening the autoclaved cement. The first two reaction products were susceptible to reactions with sulfuric acid and sodium sulfate to form crystalline bassanite scale as the corrosion product. The boehmite phase possessed a great resistance to acid and sulfate. Although the bassanite scales clinging to the cement's surfaces were the major factor governing the loss in weight, they served in protecting the cement from further acid- and sulfate-corrosion until their spallation eventually occured. Nevertheless, the repetitive processes of HOAp and hydorgrossular $\rightarrow$ bassanite $\rightarrow$ spallation played an important role in extending the useful lifetime of CaP cement in a low $\mathrm{pH}$ environment at $180^{\circ} \mathrm{C}$.
\end{abstract}




\section{Introduction}

Brookhaven National Laboratory, in collaboration with two industrial partners, Unocal Corporation and Halliburton, have formulated a calcium aluminate phosphate (CaP) cement during a research program aimed at developing the $\mathrm{CO}_{2}$ - and mild acid-resistant cementing material for geothermal wells [1,2]. This cement was composed of two major components; the calcium aluminate cement (CAC) as the solid base reactant, and an aqueous solution of sodium polyphosphate $(\mathrm{NaP})$ as the cement-forming acid reactant. When the cement slurry made by mixing these components was placed in a geothermal well at temperatures ranging from $150^{\circ}$ to $300^{\circ} \mathrm{C}$, it hardened through two steps; an exothermic acid-base reaction and the hydrothermal hydration. Two reaction products, hydroxyapatite $\left[\mathrm{Ca}_{5}\left(\mathrm{PO}_{4}\right)_{3}(\mathrm{OH}), \mathrm{HOAp}\right]$ and boehmite $(\gamma-\mathrm{AlOOH})$, were responsible for strengthening the hardened cement and for alleviating its carbonation by $\mathrm{CO}_{2}(>40,000$ $\mathrm{ppm})$ and its erosion by the attack of mild acid brine $(\mathrm{pH} \sim 5)$ at a bottom hole depth of $\sim$ $1,700 \mathrm{~m}$.

Over the past couple of years, great attention was focused on evaluating the resistance of this cement to a very strong acid environment at $\mathrm{pH}<1.5$ containing $5,000 \mathrm{ppm} \mathrm{CO} \mathrm{CO}_{2}$ at temperatures up to $180^{\circ} \mathrm{C}$, encountered in an upper well region between the well's surface and $\sim 1,140 \mathrm{~m}$ depth. As part of ongoing evaluations, one of our concerns was the effect of set retarders on the extent of the cement's acid erosion. A set retarder is an inevitable additive in formulating cement slurry for completing deep and hot geothermal wells, and it imparts an extended pumpability of the cement slurry in the down hole pumping operation. Pumpability is associated directly with thickening time allowing long enough for cement to fill up the space between the metallic casing pipe and the wall's foundation before it sets. Among the various different retarders, the citric acid commonly is used for $\mathrm{CaP}$ cement. However, there has been virtually no study of the resistance of the citric acid-retarded cement to a strong acid containing some $\mathrm{CO}_{2}$. For comparison with this organic retarder, we also used $\mathrm{NaCl}$, known as one of the inorganic retarders of $\mathrm{CaP}$ cement.

To obtain this information, we explored the following six parameters: 1) the $\mathrm{pH}$ values of the pore solution in the retarded cement slurries; 2) the beginning of setting temperature, and the total energy generated in exothermal acid-base reactions; 3 ) the 
reaction products formed by interactions between the cement and the retarder; 4) the porosity and compressive strength of autoclaved cements before exposure to acid; 5) the composition of phases formed in autoclaved cement bodies; and, 6) the identification of corrosion products of the cement after exposure to acid. All the information was integrated and correlated directly with the weight loss caused by acid erosion of the retarded cements after exposure for 20 days to $\mathrm{H}_{2} \mathrm{SO}_{4}$ solution $(\mathrm{pH}, 1.1)$ containing $3000 \mathrm{ppm} \mathrm{CO}_{2}$ at $180^{\circ} \mathrm{C}$.

\section{Experimental}

Secar 51 calcium aluminate cement (CAC), supplied by Lafarge Aluminates Corporation, was used as the base solid reactant. The X-ray powder diffraction (XRD) data showed that Secar 51 had three major crystalline components, gehlenite $\left(2 \mathrm{CaO} \cdot \mathrm{Al}_{2} \mathrm{O}_{3} \cdot \mathrm{SiO}_{2}\right.$, $\left.\mathrm{C}_{2} \mathrm{AS}\right)$, monocalcium aluminate $\left(\mathrm{CaO} \cdot \mathrm{Al}_{2} \mathrm{O}_{3}, \mathrm{CA}\right)$, and pervoskite $\left(\mathrm{CaTiO}_{3}\right)$. XRD data (Philips Electronic Instruments) was recorded using nickel-filtered $\mathrm{Cu} \mathrm{K} \alpha$ radiation at 40 $\mathrm{kV}$ and $20 \mathrm{~mA}$. Granular sodium polyphosphate, $-\left[-\left(-\mathrm{Na}^{+} \mathrm{PO}_{3}^{-}\right)_{\mathrm{n}^{-}}, \mathrm{NaP}\right]$, was supplied by the Aldrich Chemical Company Inc. The NaP then was dissolved in water to make a $25 \mathrm{wt} \%$ solution for use as the cement-forming acid aqueous reactant. Organic citric acid, $\left[\mathrm{HOC}\left(\mathrm{CO}_{2} \mathrm{H}\right)\left(\mathrm{CH}_{2} \mathrm{CO}_{2} \mathrm{H}\right)_{2}\right]$, also was obtained from the Aldrich Chemical Company and the sodium chloride, $\mathrm{NaCl}$, was used as reference inorganic retarder.

The formula of the neat cement slurry was $62 \mathrm{wt} \% \mathrm{CAC}$ and $38 \mathrm{wt} \% \mathrm{NaP}(25$ wt $\%$ solution). Before mixing thoroughly these two components, the retarder at $2,4,6$, and $8 \%$ by weight of the total amount of $\mathrm{CAC}$ was dissolved in the $\mathrm{NaP}$ solution at room temperature. Retarded and non-retarded cement slurries were cast in cylindrical molds ( $30 \mathrm{~mm}$ diam. and $70 \mathrm{~mm}$ long), and left for 24 hours to harden at room temperature. The hardened specimens then were exposed for 20 hours in an autoclave at $180^{\circ} \mathrm{C}$ before immersing them for 20 days in the $\mathrm{H}_{2} \mathrm{SO}_{4}$ solution ( $\mathrm{pH} 1.1$ ) containing $0.5 \mathrm{wt} \%$ sodium hydrogen carbonate $\left(\mathrm{NaHCO}_{3}\right)$ as a source of $\sim 3000 \mathrm{ppm} \mathrm{CO} 2$ at $180^{\circ} \mathrm{C}, \mathrm{H}_{2} \mathrm{SO}_{4}+$ $2 \mathrm{NaHCO}_{4} \rightarrow \mathrm{Na}_{2} \mathrm{SO}_{4}+2 \mathrm{CO}_{2}+2 \mathrm{H}_{2} \mathrm{O}$. To maintain the $\mathrm{pH}$ at 1.1, the $\mathrm{H}_{2} \mathrm{SO}_{4}$ solution was replenished with a fresh solution every 5 days. The volume proportion of the cement specimens to the acid solution was 1 to 25 . 
A non-isothermal differential scanning calorimeter (DSC, DuPont 910) with a heating rate of $10^{\circ} \mathrm{C} / \mathrm{min}$. in $\mathrm{N}_{2}$ gas was used to determine the onset temperature of setting and to obtain the total energy generated in an acid-base exothermic reaction. The phases formed in the autoclaved cement bodies before and after exposure to acid was identified using XRD and Fourier Transform Infrared Spectroscopy (FT-IR, Perkin Elmer Model 1600). These techniques also were used in exploring the phase transition occurring in a superficial layer of the cement after exposure to acid. The image analysis was performed by the scanning electron microscopy (SEM). The porosity of autoclaved cements was determined by helium comparison pyconometry (Micromeritrics, AccuPyc 1330). The compressive strength was determined from the average of three specimens.

\section{Results and discussion}

\section{Cement Slurry}

Before mixing the $\mathrm{NaP}$ solution with the $\mathrm{CAC}$, we investigated the changes in $\mathrm{pH}$ value of the citric acid- and $\mathrm{NaCl}$-dissolved $\mathrm{NaP}$ solution as a function of the content of the retarder (Figure 1). The NaP solution without any retarders was acidic, at $\mathrm{pH}$ 4.8. To understand the chemistry of the NaP dissociated in the water, we analyzed a solid substance precipitated after drying a NaP solution at $100^{\circ} \mathrm{C}$ by FT-IR. For comparison, the "as-received" NaP granular material was used as the reference. Figure 2 illustrates the FT-IR spectra for these samples over the frequency range from 4500 to $480 \mathrm{~cm}^{-1}$. The spectrum (a) of the "as-received" NaP granular had ten representative absorption bands at $3437,2896,1643,1290,1155,1096,1008,879,773$, and $720 \mathrm{~cm}^{-1}$. Two bands at 3437 and $1643 \mathrm{~cm}^{-1}$ are attributed to the stretching and bending vibration of $\mathrm{OH}$ group in water adsorbed on the granular surfaces. A very weak band at $2896 \mathrm{~cm}^{-1}$ may be due to the stretching mode of $\mathrm{P}-\mathrm{OH}$ as the end group of the chain conformation [3]. The presence of the stretching mode of $\mathrm{P}=\mathrm{O}$ double bond in the polyphosphate structure can be recognized from the band at $1290 \mathrm{~cm}^{-1}$ [3]. The band at $1155 \mathrm{~cm}^{-1}$ is assignable to the $\mathrm{Na}$ cation vibration on its oxygen cage [4]. The two bands at 1096 and $1008 \mathrm{~cm}^{-1}$ refelect the stretching of ionic P-O group. The band at $879 \mathrm{~cm}^{-1}$ is the stretching of P-O-P linkage in the chain conformation, and the bending mode of its linkage corresponds to the bands at 773 and $720 \mathrm{~cm}^{-1}[5]$. When this granular substance was dissolved in water, the FT-IR 
spectral features (b) of its dried sample were strikingly different; in particular, the P-O-P linkage-related bands of the granular sample had disappered, while the P-OH stretching at $2896 \mathrm{~cm}^{-1}$ had become one of the prominent bands and the band related to the $\mathrm{Na}$ cation vibration slightly shifted in a high frequency site to $1160 \mathrm{~cm}^{-1}$. All the bands seemed to belong to sodium dihydrogen phosphate, $\mathrm{Na}^{+} \mathrm{H}_{2}\left(\mathrm{PO}_{4}\right)^{-}$[3], verifying that $\mathrm{NaP}$ readily dissolves in an aqueous medium to form the $\mathrm{Na}^{+} \mathrm{H}_{2}\left(\mathrm{PO}_{4}\right)^{-}$, $-\left[-\mathrm{Na}^{+} \mathrm{PO}_{3}^{-}{ }^{-}\right]_{n^{-}}+\mathrm{H}_{2} \mathrm{O}$ $\rightarrow \mathrm{Na}^{+} \mathrm{H}_{2}\left(\mathrm{PO}_{4}\right)^{-}$. Thus, the formation of soluble $\mathrm{Na}^{+} \mathrm{H}_{2}\left(\mathrm{PO}_{4}\right)^{-}$is explicable as the acidity.

Interestingly, as Figure 1 shows, adding $\mathrm{NaCl}$ to the $\mathrm{NaP}$ enhanced its acidity. In fact, the $\mathrm{pH}$ of $\mathrm{NaP}$ solution dropped as much as $17 \%$ to 4.0 when $8 \mathrm{wt} \% \mathrm{NaCl}$ was incorporated. However, we did not further explore why $\mathrm{NaCl}$ lowers the $\mathrm{pH}$ of $\mathrm{NaP}$ solution. As expected, the NaP solution became a strong acid as citric acid was added. For instance, adding $8 \mathrm{wt} \%$ citric lowered the $\mathrm{pH}$ of the $\mathrm{NaP}$ solution to 2.6 . We note that the $\mathrm{pH}$ of the $8 \mathrm{wt} \%$ citric acid in water was 1.8 .

Next, we prepared the slurries by mixing for 3 minutes these retarder-dissolved $\mathrm{NaP}$ solutions and the $\mathrm{CAC}$. The pore solution was extracted by centrifugal separation from the 3-min-old slurries and its $\mathrm{pH}$ determined. Figure 3 plots the $\mathrm{pH}$ value against the concentration of retarder in the slurries. The $\mathrm{pH}$ of the pore solution of the $\mathrm{CAC}$ slurry made with cement to water ratio of 1.0 was 11.1 , representing a strong base. The pore solution extracted from the mixture of the $\mathrm{CAC}$ base solid and $\mathrm{NaP}$ acid solution was neutral at $\mathrm{pH} 7.1$. When these retarders were incorporated, there was a transition from neutral to acidic in the pore solution. With the $8 \mathrm{wt} \%$ retarder, the $\mathrm{pH}$ of pore solutions fell to $\mathrm{pH} 5.6$ with the $\mathrm{NaCl}$, and to $\mathrm{pH} 5.28$ with the citric acid.

Figure 4 shows the non-isothermal DSC curves for NaCl-retarded and nonretarded cement slurries. The curves depict a typical exothermic feature as a function of temperature. For the non-retarded slurry denoted as " $0 \%$ ", the exothermic curve displays its onset, $T_{o}$, at $54.3^{\circ} \mathrm{C}$ and its peak, $T_{p}$, at $58.9^{\circ} \mathrm{C}$, demonstrating that the acid-base reaction of slurry begins at $54.3^{\circ} \mathrm{C}$. Because the enclosed area of the curve with the baseline represents the total heat energy generated during the exothermic acid-base reaction, the exothermic energy, $\Delta H, \mathrm{~J} / \mathrm{g}$, can be computed using the formula $[6,7]$, $\Delta H=T R A / h m$, 
where $T, R, A, h$ and $m$ refer to the temperature scale $\left({ }^{\circ} \mathrm{C} \mathrm{in}^{-1}\right.$ ), the range sensitivity (mcal $\left.\mathrm{s}^{-1} \mathrm{in}^{-1}\right)$, the peak area $\left(\mathrm{in}^{2}\right)$, the heating rate $\left({ }^{\circ} \mathrm{C} \mathrm{s}^{-1}\right)$, and the sample's weight (mg), respectively. The computed $\Delta H$ for non-retarded slurries was $87.3 \mathrm{~J} / \mathrm{g}$. Adding $2 \mathrm{wt} \%$ $\mathrm{NaCl}$ retarder shifted the onset and peak positions to $62.2^{\circ} \mathrm{C}$ and $65.5^{\circ} \mathrm{C}$, respectively, suggesting that $\mathrm{NaCl}$ raises the setting temperature of the slurry. A further shift to the high-temperature side was recorded from $4 \mathrm{wt} \% \mathrm{NaCl}$-incorporated slurry; the onset for 6 and $8 \mathrm{wt} \% \mathrm{NaCl}$ was $86.9^{\circ}$ and $104.5^{\circ} \mathrm{C}$, respectively. Comparing the peak area for each curve showed that it tends to diminish with an increasing amount of $\mathrm{NaCl}$, demonstrating that its incorporation reduces the exothermic reaction energy. In other words, adding $\mathrm{NaCl}$ inhibits the acid-base reaction.

A similar trend in shifting the onset and peak positions to the high-temperature side was observed from the DSC curves of the citric acid-incorporated slurries (Figure 5). However, the features of the curves distinctively differed from those with $\mathrm{NaCl}$; particularly, the peak area tends to increase with an increasing amount of citric acid. In addition, when the onset and peak temperatures in exothermic curves for each of the 2,4 , 6 , and $8 \mathrm{wt} \%$ citric acid were compared with those with the same amount of the $\mathrm{NaCl}$, the former values were much higher than those of the $\mathrm{NaCl}$. Thus, we believe that the citric acid performs better in increasing the setting temperature and prolonging the setting time of the cement slurry, and yet promotes the rate of the acid-base reaction.

Table 1 lists all the information on the onset and peak temperatures of the DSC curves and the exothermic reaction energies, $\Delta H$, computed from the total area of curve for the $\mathrm{NaCl}$ - and citric acid-incorporated cement slurries. Regarding the $\Delta H$, its value of the non-retarded cement was considerably reduced with the increase in amount of the $\mathrm{NaCl}$. For instance, the $8 \mathrm{wt} \%$-retarded slurry generated an exothermic energy of only 5.9 $\mathrm{J} / \mathrm{g}$, which is $\sim 15$ times lower than that of the non-retarded one, proving that $\mathrm{NaCl}$ inhibits the acid-base exothermic reaction. In contrast, adding citric acid promoted the generation of reaction energy. For instance, at 6 and $8 \mathrm{wt} \%$, the $\Delta H$ values were computed to be 97.4 and $101.4 \mathrm{~J} / \mathrm{g}$, respectively, corresponding to $\sim 12 \%$ and $\sim 16 \%$ increment over that of the non-retarded cement. 
From integrating all information described above, we concluded that the chemistry of citric acid-retarded cement slurry is quite different from that of the $\mathrm{NaCl}$ retarded slurry.

\section{Reaction Products between the Retarders and CAC}

In exploring the chemistry of the citric acid- and $\mathrm{NaCl}$-treated slurries, our focus centered on identifying the reaction products formed by the interactions between the retarder and $\mathrm{CAC}$ reactant. In this study, the retarders were dissolved in deionized water to make $8 \mathrm{wt} \%$ retarding aqueous solution. The $40 \mathrm{wt} \%$ ( $8 \mathrm{wt} \%$ retarding solution) then was mixed with $60 \mathrm{wt} \% \mathrm{CAC}$, and left for 20 hours at room temperature until it become a solid mass. Afterward, this solid mass was dried for 24 hours at $90^{\circ} \mathrm{C}$, and then was pulverized into particles of $<20 \mu \mathrm{m}$ for FT-IR analysis.

Figure 6 shows the spectra of the $\mathrm{NaCl}$-incorporated CAC sample (a) and the two reference samples, $\mathrm{NaCl}$ granular (b) and non-reacted $\mathrm{CAC}$ grains (c). Compared with these references, the spectral feature of $\mathrm{NaCl}$-modified $\mathrm{CAC}$ samples was characterized by the appearance of a new peak at $532 \mathrm{~cm}^{-1}$; meanwhile, all the bands related to the nonreacted CAC still remained in the frequency range from 1020 to $632 \mathrm{~cm}^{-1}$. We assumed that this new band reflected the formation of calcium chloride, $\mathrm{CaCl}_{2} \cdot \mathrm{xH}_{2} \mathrm{O}$, as the reaction product yielded by the interactions between $\mathrm{Ca}^{2+}$ cations dissociated from $\mathrm{CAC}$ and $\mathrm{Cl}^{-}$anions from $\mathrm{NaCl}$. To validate this assumption, we inspected the FI-IR spectrum of calcium chloride dihydrate granular, supplied from Alfa Aesar Company. The spectrum (not shown) had four pronounced peaks at 3510,3425, 1625, and $532 \mathrm{~cm}^{-1}$. Thus, this new band along with the $\mathrm{OH}$ stretching and bending modes at 3519,3460 , and $1614 \mathrm{~cm}^{-1}$ appears to be associated with the formation of $\mathrm{CaCl}_{2} \cdot \mathrm{xH}_{2} \mathrm{O}$. The FT-IR spectrum of the citric acid-modified CAC sample (a), which is shown in Figure 7, includes the spectra of two reference samples, the non-reacted CAC grains (c) and the citric acid granular (b). The spectral features of the citric acid-modified CAC samples strikingly differed from that of citric acid granular. Among the differences is the elimination of most of the citric acid-related peaks and the development of new bands at 1584 and $1407 \mathrm{~cm}^{-1}$ attributed to the alkaline metal-complexed carboxylate groups (metal ${ }^{+}$-OOC-) [8]. When the CAC grain's surface come in contact with water, the two 
major reactant phases in $\mathrm{CAC}$, gehlenite $\left(2 \mathrm{CaO} . \mathrm{Al}_{2} \mathrm{O}_{3} \cdot \mathrm{SiO}_{2}, \mathrm{C}_{2} \mathrm{AS}\right)$ and monocalcium aluminate $\left(\mathrm{CaO} . \mathrm{Al}_{2} \mathrm{O}_{3}, \mathrm{CA}\right)$, undergo hydrolysis and dissociate into three ionic species, $2 \mathrm{Ca}^{2+}, 2 \mathrm{Al}(\mathrm{OH})_{4}^{-}$, and $\mathrm{H}_{3} \mathrm{SiO}_{4}^{-}$from $\mathrm{C}_{2} \mathrm{AS}$ [9], and release $\mathrm{Ca}^{2+}$ and $\mathrm{Al}(\mathrm{OH})_{4}^{-}$from $\mathrm{CA}$ [10]. From this dissociation, the $\mathrm{Ca}^{2+}$ ion becomes the source of cationic metal species in this carboxylate complex. Hence, it is possible to assume that the complexity was yielded by the interactions between the carboxylic acid group (-COOH) within the citric acid and the $\mathrm{Ca}^{2+}$ from CAC.

Assuming that the primary theory of set retardation for conventional portland cements is adaptable to the retarded $\mathrm{CaP}$ cements, the following hypothetical mechanism for $\mathrm{NaCl}$ can be drawn. The uptake of the $\mathrm{Cl}^{-}$anion dissociated from $\mathrm{NaCl}$ in the $\mathrm{NaP}$ solution by the $\mathrm{Ca}^{2+}$ cation liberated from the hydrolysis of the CAC grain's surfaces led to the precipitation of $\mathrm{CaCl}_{2} \cdot \mathrm{xH}_{2} \mathrm{O}$ reaction products on the hydrolyzed $\mathrm{CAC}$ grains' surfaces. This precipitated reaction product may act as set-retarding barrier layer that inhibits the cement-forming acid-base reactions between $\mathrm{CAC}$ and NaP. As described earlier in the DSC study, although the onset temperature of the cement-forming reactions was increased as more $\mathrm{NaCl}$ was added, such incorporation caused a conspicuous decay in the exothermic energy generated by the acid-base interactions between the CAC and $\mathrm{NaP}$. Hence, the $\mathrm{CaCl}_{2} \cdot \mathrm{xH}_{2} \mathrm{O}$-related barrier layers precipitated on the $\mathrm{CAC}$ grains' surfaces may thicken with an increasing amount of $\mathrm{NaCl}$. Once thick layers were formed, they persistently prohibited the contact of the $\mathrm{CAC}$ with $\mathrm{NaP}$. In other words, this setretarding barrier layer possesses resistance to the breakage caused by the following two possible factors: One is attack by the free $\mathrm{Ca}^{2+}$ liberated newly from $\mathrm{CAC}$; the other is related to disintegration at high temperature. In contrast, even though a thick $\mathrm{Ca}^{2+}{ }^{-} \mathrm{OOC}-$ complexity barrier layer was deposited on the $\mathrm{CAC}$ grain's surfaces, this set-retarding layer may be vulnerable to breakage caused by these two factors. If this interpretation is valid, a substantial amount of $\mathrm{Ca}^{2+}$ trapped in this thick layer might diffuse into the NaP solution after its disintegration. The diffused $\mathrm{Ca}^{2+}$ cations then react with $\mathrm{Na}^{+} \mathrm{H}_{2} \mathrm{PO}_{4}{ }^{-}$to generate acid-base exothermic energy. Hence, as recorded in DSC study, the disintegration at high temperature of $\mathrm{Ca}^{2+}$-rich complexed layers formed by incorporating a large amount of citric acid contributed to a great deal of the exothermic energy. 
To verity that these reaction products also are formed in the retarded cements, we analyzed by FT-IR the hardened cement samples prepared by mixing the $\mathrm{CAC}$ and $\mathrm{NaP}$ solution with and without $8 \mathrm{wt} \% \mathrm{NaCl}$ or $8 \mathrm{wt} \%$ citric acid at room temperature. Figure 8 gives their FT-IR spectra. In the spectrum of non-retarded cement (a), the band at 1079 $\mathrm{cm}^{-1}$ reveals the formation of typical orthophosphate $\left(\mathrm{PO}_{4}\right)$ groups in the calcium phosphate compounds, produced by acid-base reactions between $\mathrm{CAC}$ and $\mathrm{NaP}$. The $\mathrm{O}-\mathrm{H}$ stretching band in the $\mathrm{H}_{2} \mathrm{O}$ at $3413 \mathrm{~cm}^{-1}$ probably was associated with the hydrated calcium phosphate compound; the several remaining peaks belong to the non-reacted CAC. Similar spectral features, except for the band at $530 \mathrm{~cm}^{-1}$, were observed from the $\mathrm{NaCl}$-retarded cement (b). Since the band at $530 \mathrm{~cm}^{-1}$ is assignable to the formation of $\mathrm{CaCl} . \mathrm{xH}_{2} \mathrm{O}$ as set-retarding reaction product, we proved that this reaction product also is formed in the cement bodies at room temperature. The major characteristic of the spectrum of the citric acid-retarded cement (c) was the appearance of two prominent bands at 1589 and $1412 \mathrm{~cm}^{-1}$ attributed to the Ca-complexed carboxylate compound as the set-retarding reaction product. The other remaining bands represent the hydrated calcium phosphate compound and non-reacted CAC. Again, this finding can be taken as evidence that the $\mathrm{Ca}^{2+}$ COO- complexity also is formed in the cement bodies and it serves in increasing the onset temperature of setting and in extending the setting time.

\section{Autoclaved CaP Cement}

Our study next shifted to measuring the compressive strength and porosity of the retarded cement specimens after autoclaving them for 24 hours at $180^{\circ} \mathrm{C}$, and to identifying the phases assembled in the autoclaved cement bodies. Table 2 gives the changes in porosity and compressive strength for the autoclaved cement specimens as a function of the concentration of retarder. They show that the porosity of the cements containing either $\mathrm{NaCl}$ or citric acid retarders tends to decline as their amount is increased; with the $8 \mathrm{wt} \%$ retarder, the porosity of non-retarded cement was reduced $\sim 7.2 \%$ to $43.8 \%$ for $\mathrm{NaCl}$, and by $\sim 11.4 \%$ to $41.8 \%$ for citric acid. This finding suggested that the structure of cements modified with these retarders becomes denser. Regarding the compressive strength, its value decreases with the increase in amount of these retarders. Furthermore, adding $\mathrm{NaCl}$ 
markedly restrained the development of compressive strength. In fact, at only $2 \mathrm{wt} \%$ $\mathrm{NaCl}$, its value was less than $50 \%$ of that of the non-retarded cement. Further incorporation to $8 \mathrm{wt} \%$ caused a serious reduction in compressive strength to $4.32 \mathrm{MPa}$. By comparison, the rate of its reduction by the citric acid was much less than that caused by $\mathrm{NaCl}$. In fact, adding $2 \mathrm{wt} \%$ citric acid lowered strength of only by around $10 \%$. At $8 \mathrm{wt} \%$, the reduction was $38 \%$. Relating this finding to the DSC exothermic reaction energy, the development of strength in the retarded cements is likely to be associated with the extent of the reaction energy generated. The generation of a lower level of energy caused by adding $\mathrm{NaCl}$ was detrimental to strengthening the cement. Since citric acid promoted reaction energy, this is the reason why the compressive strength of cements retarded with it exhibited a minimal reduction.

Figure 9 compares the XRD features of the non-retarded, and $8 \mathrm{wt} \% \mathrm{NaCl}$ - or citric acid-retarded cements after autoclaving for 24 hours at $180^{\circ} \mathrm{C}$, over the diffraction range of $0.356-0.201 \mathrm{~nm}$. There is no marked distinction between them; namely, the cement bodies made with and without the retarders were assembled by hybrid phases involving hydroxyapatite $\left[\mathrm{Ca}_{5}\left(\mathrm{PO}_{4}\right)_{3}(\mathrm{OH}), \mathrm{HOAp}\right]$, boehmite $(\gamma$-AlOOH$)$, hydrogrossular, $\left(3 \mathrm{CaO} . \mathrm{Al}_{2} \mathrm{O}_{3} .6 \mathrm{H}_{2} \mathrm{O}, \mathrm{C}_{3} \mathrm{AH}_{6}\right)$, and non-reacted pervoskite $\left(\mathrm{CaTiO}_{3}\right)$ as the major phases, and the non-reacted monocalcium aluminate $\left(\mathrm{CaO} . \mathrm{Al}_{2} \mathrm{O}_{3}, \mathrm{CA}\right)$ as the minor one. We assumed that among the three crystalline reaction products, HOAp, boehmite and hydrogrossular, which are responsible for strengthening the autoclaved cements, the first two phases are yielded through the following two step reaction pathways, hydrolysis and hydrothermal interactions.

Hydrolysis of reactants:

$2 \mathrm{CaO} \cdot \mathrm{Al}_{2} \mathrm{O}_{3} \cdot \mathrm{SiO}_{2}+5 \mathrm{H}_{2} \mathrm{O}+\mathrm{OH} \rightarrow 2 \mathrm{Ca}^{2+}+2 \mathrm{Al}(\mathrm{OH})_{4}{ }^{-}+\mathrm{H}_{3} \mathrm{SiO}_{4}^{-}$

$\mathrm{CaO} . \mathrm{Al}_{2} \mathrm{O}_{3}+4 \mathrm{H}_{2} \mathrm{O} \rightarrow \mathrm{Ca}^{2+}+2 \mathrm{Al}(\mathrm{OH})_{4}^{-}$,

$-\left[-\mathrm{NaPO}_{3}-\right]_{\mathrm{n}^{-}}+\mathrm{H}_{2} \mathrm{O} \rightarrow \mathrm{Na}^{+} \mathrm{H}_{2} \mathrm{PO}_{4}^{-}$,

Hydrothermal interactions:

$\mathrm{Ca}^{2+}+\mathrm{Na}^{+} \mathrm{H}_{2} \mathrm{PO}_{4}^{-}+\mathrm{xH}_{2} \mathrm{O} \rightarrow \mathrm{Ca}\left(\mathrm{HPO}_{4}\right) \cdot \mathrm{xH}_{2} \mathrm{O}+\mathrm{Na}^{+}+\mathrm{H}^{+}$,

$\mathrm{Ca}\left(\mathrm{HPO}_{4}\right) \cdot \mathrm{xH}_{2} \mathrm{O}+4 \mathrm{Ca}^{2+}+2 \mathrm{Na}^{+} \mathrm{H}_{2} \mathrm{PO}_{4}^{-} \rightarrow \mathrm{Ca}_{5}\left(\mathrm{PO}_{4}\right)_{3}(\mathrm{OH})+2 \mathrm{Na}^{+}+\mathrm{xH}^{+}+\mathrm{yOH}$, 
$\mathrm{Al}(\mathrm{OH})_{4}{ }^{-}+\mathrm{H}^{+} \rightarrow \mathrm{AlH}(\mathrm{OH})_{4} \rightarrow \gamma-\mathrm{AlOOH}+2 \mathrm{H}_{2} \mathrm{O}$

Concurrently, hydrogrossular may be formed through the following hydrothermal interaction between the hydrolysate species; $3 \mathrm{Ca}^{2+}+2 \mathrm{Al}(\mathrm{OH})_{4}{ }^{-}+4 \mathrm{OH}^{-} \rightarrow$ $3 \mathrm{CaO} \cdot \mathrm{Al}_{2} \mathrm{O}_{3} \cdot 6 \mathrm{H}_{2} \mathrm{O}$.

Figure 10 illustrates the FT-IR spectra of the same samples as those used in the XRD study. Spectrum (a) of the $180^{\circ} \mathrm{C}$-autoclaved cement without a retarder encompassed the bands at 3660 and $1584 \mathrm{~cm}^{-1}$, ascribed to the $\mathrm{O}-\mathrm{H}$ stretching and bending modes in $\mathrm{H}_{2} \mathrm{O}$, the bands at 3307, 3096, 1071, 741, and $602 \mathrm{~cm}^{-1}$, revealing the boehmite [11], the band around $1451 \mathrm{~cm}^{-1}$, belonging to the $\mathrm{CO}_{3}$ in the carbonated cement [12], and the bands at 571 and $516 \mathrm{~cm}^{-1}$, seemingly associated with the hydrogrossular. The band at $1071 \mathrm{~cm}^{-1}$ not only relates to the Al-O-H bending mode in the boehmite, but also contributes to the P-O stretching mode in the HOAp phase [13]. The spectral features of the $\mathrm{NaCl}$ - and citric acid-retarded cements closely resembled that of the non-retarded cement. Also, there were no bands related to the set-retarding reaction products, such as the carboxylate complexity and $\mathrm{CaCl}_{2} \cdot \mathrm{xH}_{2} \mathrm{O}$. However, we did not explore the reasons why these reaction products were eliminated during autoclaving.

\section{Resistance to $\mathrm{CO}_{2}$-laden Acid}

Figure 11 depicts the loss in weight of the $\mathrm{NaCl}$ - and citric acid-retarded cements after exposure for 20 days to the $\mathrm{CO}_{2}$-laden $\mathrm{H}_{2} \mathrm{SO}_{4}$ solution at $180^{\circ} \mathrm{C}$. We observed that the entire surfaces of all the exposed specimens were covered with the crystalline corrosion products of cement. To identify the chemical state of the corrosion products, they were removed and analyzed by SEM and XRD (Figure 12): this crystalline corrosion product is bassanite $\left(\mathrm{CaSO}_{4} \cdot 1 / 2 \mathrm{H}_{2} \mathrm{O}\right)$, together with some non-reacted perovskite. All the corrosion products clinging to the surfaces of exposed cements were brushed off before measuring their weight. The loss of weight recorded for both the $\mathrm{NaCl}$ - and citric acidretarded cements tends to increase with an increasing amount of retarders. However, the loss in weight with the citric acid was much lower than that with $\mathrm{NaCl}$. In fact, with $8 \mathrm{wt} \%$ retarder, the weight loss of the $\mathrm{NaCl}$ - and citric acid-modified cements was $\sim 31 \%$ 
and $\sim 26 \%$, corresponding to an increment of $\sim 41 \%$ and $\sim 18 \%$, respectively, compared with that of non-retarded cement.

In addition, we analyzed the superficial layers of the cement after removing the corrosion products in an attempt to understand the acid-erosion mechanisms of the retarded and non-retarded cements. FT-IR and XRD were used to identify the phase compositions and their transitions in the superficial layers of $8 \mathrm{wt} \% \mathrm{NaCl}$-and citric acidretarded cements and non-retarded cements after exposure to acid for 20 days. The powder samples for these tests were prepared by physically abrading the cement surfaces.

Figure 13 shows FT-IR spectrum (a) of the samples taken from the superficial layer of the non-retarded cement. The data also include the spectra of two references, bassanite (b) and boehmite (c). As seen, the superficial layer was occupied by two phases: one was bassanite related to the bands at $3613,3554,1619,1155,1102,1008$, 662 , and $597 \mathrm{~cm}^{-1}$; the other was boehmite associated with the bands at 3307, 3096, 738, and $509 \mathrm{~cm}^{-1}$. The same result was obtained from the XRD analysis (not shown). Neither HOAp nor hydrogrossular was present in the superficial layers. We anticipated the formation of ettringite $\left(3 \mathrm{CaO} \cdot \mathrm{Al}_{2} \mathrm{O}_{3} \cdot 3 \mathrm{CaSO}_{4} \cdot 32 \mathrm{H}_{2} \mathrm{O}\right)$, which might be yielded by reactions between the hydrogrossular and $\mathrm{CaSO}_{4}$; however, no ettringite phase was found in the superficial layers. The FT-IR and XRD data for the retarded cements were almost the same as that from the non-retarded cement (data not shown), suggesting that the HOAp and hydrogrossular phases are vulnerable to acid attack. These phases were transferred into the bassanite phase as the corrosion product during exposure to $\mathrm{CO}_{2}$ laden $\mathrm{H}_{2} \mathrm{SO}_{4}$ solution at $180^{\circ} \mathrm{C}$. Incorporating $\mathrm{NaHCO}_{3}$ into $\mathrm{H}_{2} \mathrm{SO}_{4}$ solution not only causes the evolution of the $\mathrm{CO}_{2}$ gas, but also yields some sodium sulfate, $\mathrm{Na}_{2} \mathrm{SO}_{4}$. Hence, the HOAp and hydrogrossular $\rightarrow$ bassanite phase transition was initiated by their reactions with two reactants, sulfuric acid and sodium sulfate. With sulfuric acid, bassanite was formed through following possible interactions; $\mathrm{Ca}_{5}\left(\mathrm{PO}_{4}\right)_{3}(\mathrm{OH})+5 \mathrm{H}_{2} \mathrm{SO}_{4}$ $\rightarrow 5 \mathrm{CaSO}_{4}+3 \mathrm{H}_{3} \mathrm{PO}_{4}+\mathrm{H}_{2} \mathrm{O}$, and $3 \mathrm{CaO} \cdot \mathrm{Al}_{2} \mathrm{O}_{3} \cdot 6 \mathrm{H}_{2} \mathrm{O}+3 \mathrm{H}_{2} \mathrm{SO}_{4} \rightarrow 3 \mathrm{CaSO}_{4}+.2 \mathrm{Al}(\mathrm{OH})_{3}+$ $6 \mathrm{H}_{2} \mathrm{O}$. For sodium sulfate, these reactions are as follows; $\mathrm{Ca}_{5}\left(\mathrm{PO}_{4}\right)_{3}(\mathrm{OH})+5 \mathrm{Na}_{2} \mathrm{SO}_{4} \rightarrow$ $5 \mathrm{CaSO}_{4}+3 \mathrm{Na}_{3} \mathrm{PO}_{4}+\mathrm{NaOH}$, and $3 \mathrm{CaO} \cdot \mathrm{Al}_{2} \mathrm{O}_{3} \cdot 6 \mathrm{H}_{2} \mathrm{O}+3 \mathrm{Na}_{2} \mathrm{SO}_{4} \rightarrow 3 \mathrm{CaSO}_{4}+2 \mathrm{Al}(\mathrm{OH})_{3}$ $+6 \mathrm{NaOH}$. Compared with these phases, the susceptibility of boehmite phase to reactions 
with $\mathrm{H}_{2} \mathrm{SO}_{4}$ and $\mathrm{Na}_{2} \mathrm{SO}_{4}$ is negligible, implying that it displays a great resistance to acid and sulfate.

The acid-erosion mechanism of $\mathrm{CaP}$ cement can be explicated as the reduction of cement's volume caused by the spallation of crystalline bassanite scales yielded by the interactions of the acid and sulfate with HOAp and hydrogrossular in the superficial layers. Although the bassanite scales served as the primary barrier against a further acid and sulfate attack to the HOAp and hydrogrossular, their spallation eventually led to an overall loss of the cements. After spallation, the freshly disclosed HOAp and hydrogrossular phases again underwent the acid and sulfate corrosion to deposit bassanite scales onto the cement's new surfaces. However, we have no experimental evidence as to how long the bassanite barrier layer clings to the cement's surface and so remains as protection for the underlying cement against a further attack. Nevertheless, we believe that the repetitive processes of HOAp and hydrogrossular $\rightarrow$ bassanite $\rightarrow$ spallation play an essential role in extending the useful lifetime of the $\mathrm{CaP}$ cement in a low $\mathrm{pH}$ environment. This continued consumption of HOAp and hyrogrossular appears to be associated with the loss in weight and the reduction in volume of the cement. Although acid solution contained some $\mathrm{CO}_{2}$, we did not explore the role of $\mathrm{CO}_{2}$ in promoting the acid erosion of the cement.

\section{Conclusion}

An increase in the set temperature of calcium aluminate phosphate $(\mathrm{CaP})$ cement by citric acid was due to the precipitation of $\mathrm{Ca}^{2+}$-complexed carboxylate compound as a setretarding reaction product on the surfaces of the calcium aluminate cement (CAC) reactant. This carboxylate complexity was yielded by the interactions between the $\mathrm{Ca}^{2+}$ ions liberated from the $\mathrm{CAC}$ reactant and the carboxylic acid groups within citric acid. The carboxlate complexity acted as a barrier layer, which hindered contact between the $\mathrm{CAC}$ as the base solid reactant and sodium polyphosphate solution as the acid liquid reactants. This obstruction significantly increased the onset temperature of setting of the cement slurry, thereby extending its thickening time at high temperature. However, this barrier layer was vulnerable to disintegration due to the following two possible factors: One is the attack by free $\mathrm{Ca}^{2+}$ ions from $\mathrm{CAC}$; the other is associated with a degradation 
at high temperature. This directly reflected the great deal of exothermic energy generated by acid-base reactions between the $\mathrm{Ca}^{2+}$ and $\mathrm{Na}^{+} \mathrm{H}_{2}\left(\mathrm{PO}_{4}\right)^{-}$in an aqueous medium after the disintegration of barrier layers at the elevated temperature.

In contrast, the uptake of $\mathrm{Ca}^{2+}$ by the $\mathrm{NaCl}$ retardant led to the formation of a $\mathrm{CaCl}_{2} \cdot \mathrm{xH}_{2} \mathrm{O}$ reaction product as barrier layer that increased the setting temperature of slurry. Unlike the carboxlate complexity layer, this layer deposited on the CAC grain's surfaces was resistant to disintegration by further $\mathrm{Ca}^{2+}$ dissociation from $\mathrm{CAC}$ and to degradation at high temperature, causing a considerable attenuation of exothermic energy generated by acid-base reaction between reactants. Such low reaction energy was detrimental to the development of strength in the cement. Correspondingly, the compressive strength of $180^{\circ} \mathrm{C}$-autoclaved NaCl-retarded cements fell more than $45 \%$, compared with that of citric acid-modified cements.

Although some of these set-retarding reaction products still remained in the cement's bodies cured at room temperature, they were completely eliminated after exposure in the $180^{\circ} \mathrm{C}$ autoclave for 24 hours. The phase composition assembled in all the retarded and non-retarded cements' bodies after autoclaving was comprised of three reaction products and two remaining non-reacted reactants. The former included the hydroxyapatite, boehmite, and hydrogrossular, and the latter were the moncalcium aluminate and pervoskite. When the retarded and non-retarded cements were exposed for 20 days to $\mathrm{CO}_{2}$-laden acid solution at $180^{\circ} \mathrm{C}$, the acid erosion of both the citric acid- and $\mathrm{NaCl}$-retarded cements depended on the amount of retarders; the loss in weight of the cements rose as the amount of retarders increased. However, the rate of its loss with citric acid was much lower than that for $\mathrm{NaCl}$. Nevertheless, the extent of loss for all cements was related directly to the phase transition of hydroxyapatite and hydrogrossular into the crystalline bassanite scale as acid-induced corrosion product, signifying that these phases as reaction products were susceptible to reactions with $\mathrm{H}_{2} \mathrm{SO}_{4}$ and $\mathrm{Na}_{2} \mathrm{SO}_{4}$. Although the bassanite scales clinging to the cement's surfaces served as the primary barrier against further attack by acid and sulfate on the HOAp and hydrogrossular in the superficial layers, their spallation eventually led to an overall loss of weight of the cements. Nevertheless, we believe that the repetitive processes of HOAp and hydrogossular $\rightarrow$ 
bassanite $\rightarrow$ spallation play an important role in extending the useful lifetime of the $\mathrm{CaP}$ cement in a low $\mathrm{pH}$ environment at $180^{\circ} \mathrm{C}$. 
References

1. T. Sugama, N.R. Carciello, T.M. Nayberg and L.E. Brothers, Cem. Concr. Res. 25 (1995) 1305.

2. T. Sugama, Adv. Cem. Res. 9 (1997) 65.

3. E.E.C. Corbrige and E.J. Lowe, J. Chem. Soc. (1954) 493.

4. B.N. Nelson and G.J. Exarhos, J. Chem. Phys. 71, (1979) 2739.

5. L.J. Bellamy, The Infrared Spectra of Complex Molecules, Third Edition, p. 363, Chapman and Hall, London (1975).

6. M. J. O’Neal, Anal. Chem. 36 (1964) 1238.

7. M.G. Wyzgoshi, J. Appl. Polym. Sci. 25 (1980) 1455.

8. K. Nakanish and P.H. Solomon, Infrared Absorption Spectroscopy, Second Edition, p. 40, Holden-Day, Inc. San Francisco (1977).

9. E.J. Reardon, Cem. Concr. Res. 20 (1990) 175.

10. C.E. Harvie and J.H. Weare, Geochim. Consmochim. Acta. 44 (1980) 981.

11. G. Krishna, P. Padmaja, K.G.K. Warrier, A.D. Damodaran, and G. Aruldhas, J. Mater. Sci. Lett. 16 (1997) 1584.

12. M. Nagai, T. Saeki, and T. Nishino, J. Am. Ceram. Soc. 73 (1990) 1456.

13. K. Sato, T. Hashida, H. Takahashi, and N. Yamasaki, J. Mater. Sci. Lett. 16 (1997) 1464. 
Table 1. Changes in the onset and peak temperatures and the total energy on the DSC exothermic reaction curve of cement as a function of the concentration of $\mathrm{NaCl}$ and citric acid.

\begin{tabular}{|c|c|c|c|c|}
\hline NaCl, wt\% & $\begin{array}{c}\text { Citric acid, } \\
\mathbf{w t} \%\end{array}$ & $\begin{array}{c}\text { Onset } \\
\text { temperature of } \\
\text { exothermic } \\
\text { curve, } \boldsymbol{T}_{\boldsymbol{o}}{ }^{\circ} \mathbf{C}\end{array}$ & $\begin{array}{c}\text { Peak } \\
\text { temperature of } \\
\text { exothermic } \\
\text { curve, } \boldsymbol{T}_{\boldsymbol{p}},{ }^{\circ} \mathbf{C}\end{array}$ & $\begin{array}{c}\text { Exothermic } \\
\text { reaction } \\
\text { energy, } \Delta \mathbf{H}, \\
\mathbf{J} / \mathbf{g}\end{array}$ \\
\hline 0 & & 54.3 & 58.9 & 87.3 \\
\hline 2 & & 62.2 & 65.5 & 77.6 \\
\hline 4 & & 74.2 & 77.7 & 24.2 \\
\hline 6 & & 86.9 & 91.9 & 12.9 \\
\hline 8 & & 104.5 & 119.8 & 5.9 \\
\hline & 2 & 85.8 & 94.2 & 90.5 \\
\hline & 4 & 109.3 & 116.0 & 93.3 \\
\hline & 6 & 117.9 & 123.6 & 97.4 \\
\hline & 6 & 134.9 & 140.7 & 101.4 \\
\hline
\end{tabular}

Table 2. Porosity and compressive strength of retarded and non-retarded cement specimens after autoclaving at $180^{\circ} \mathrm{C}$.

\begin{tabular}{|c|c|c|c|}
\hline Retarder & $\begin{array}{c}\text { Concentration of } \\
\text { retarder, wt\% }\end{array}$ & Porosity, \% & $\begin{array}{c}\text { Compressive } \\
\text { strength, MPa }\end{array}$ \\
\hline $\mathrm{NaCl}$ & 0 & 47.2 & 12.8 \\
\hline $\mathrm{NaCl}$ & 2 & 46.6 & 6.00 \\
\hline $\mathrm{NaCl}$ & 4 & 45.3 & 5.68 \\
\hline $\mathrm{NaCl}$ & 6 & 44.7 & 4.95 \\
\hline $\mathrm{NaCl}$ & 8 & 43.8 & 4.32 \\
\hline Citric acid & 2 & 44.6 & 11.53 \\
\hline Citric acid & 4 & 42.9 & 9.02 \\
\hline Citric acid & 6 & 41.9 & 8.31 \\
\hline Citric acid & 8 & 41.8 & 7.91 \\
\hline
\end{tabular}




\section{Figure Captions}

Figure 1. Changes in $\mathrm{pH}$ value of $\mathrm{NaP}$ solutions containing $2,3,6$ and $8 \mathrm{wt} \%$ retarder.

Figure 2. FT-IR spectra for (a) "as-received" NaP granular and (b) NaP solution after drying.

Figure 3. Changes in $\mathrm{pH}$ value of pore solution extracted from cement slurries as a function of retarder content.

Figure 4. Non-isothermal DSC exothermic curves for NaCl-retarded and non-retarded cement slurries.

Figure 5. DSC exothermic curves for citric acid-retarded cement slurries.

Figure 6. FT-IR spectra for (a) NaCl-modified CAC cement and two reference samples, (b) $\mathrm{NaCl}$, and (c) $\mathrm{CAC}$.

Figure 7. FT-IR spectra for (a) citric acid-modified CAC cement and two reference samples, (b) citric acid and (c) CAC.

Figure 8. FT-IR spectra for (a) non-retarded CaP cement, (b) NaCl-retarded CaP cement, and (c) citric acid-retarded $\mathrm{CaP}$ cement cured at room temperature.

Figure 9. XRD tracings for (a) non-retarded cement, (b) $8 \mathrm{wt} \% \mathrm{NaCl}$-retarded cement, and (c) $8 \mathrm{wt} \%$ citric acid-retarded cement after autoclave for 24 hours at $180^{\circ} \mathrm{C}$.

Figure 10. FT-IR spectra for (a) non-retarded cement, (b) $8 \mathrm{wt} \%$ NaCl-retarded cement, and (c) $8 \mathrm{wt} \%$ citric acid-retarded cement after autoclaving for 24 hours at $180^{\circ} \mathrm{C}$.

Figure 11. Loss in weight of retarded and non-retarded cements after exposure for 20 days in $\mathrm{CO}_{2}$-laden acid at $180^{\circ} \mathrm{C}$.

Figure 12. SEM image and XRD pattern of the acid corrosion products formed on cement's surfaces during the 20-day exposure.

Figure 13. FT-IR spectra for (a) the sample removed from superficial layers of 20 dayexposed non-retarded cement and two reference samples, (b) bassanite and (c) boehmite. 


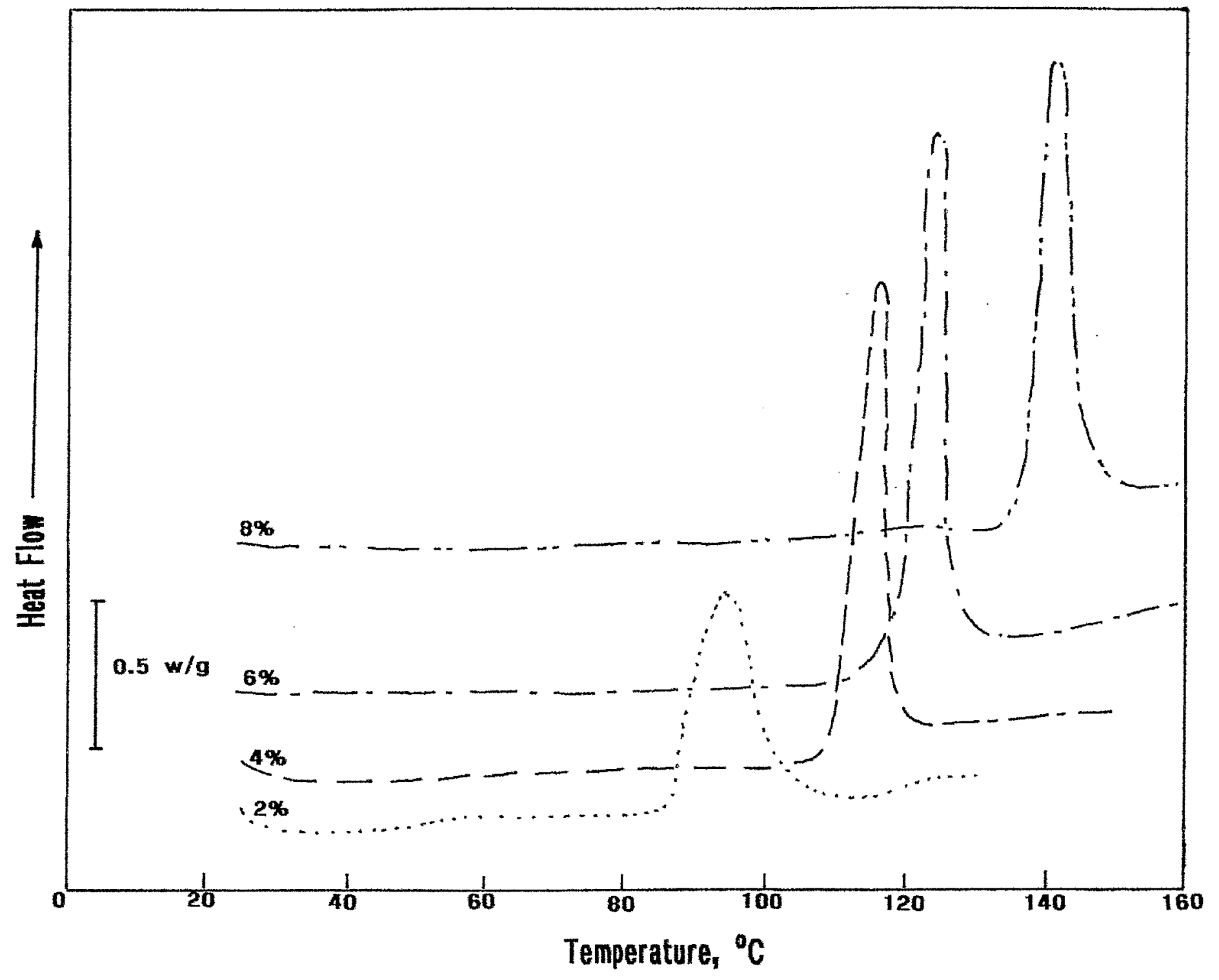

Figure 5. DSC exothermic curves for citric acid-retarded cement slurries. 


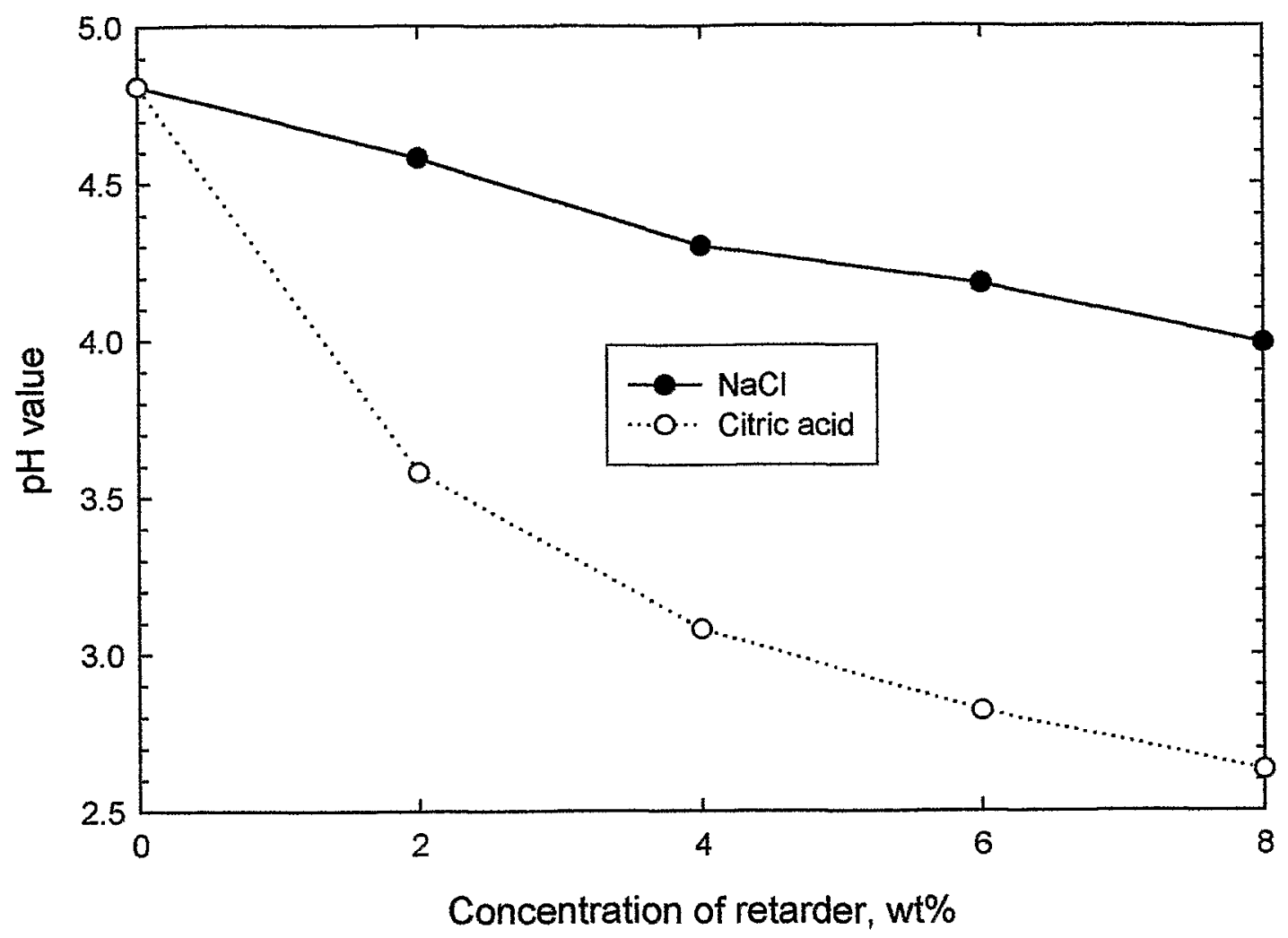

Figure 1. Changes in $\mathrm{pH}$ value of $\mathrm{NaP}$ solutions containing $2,3,6$, and $8 w t \%$ retarder. 


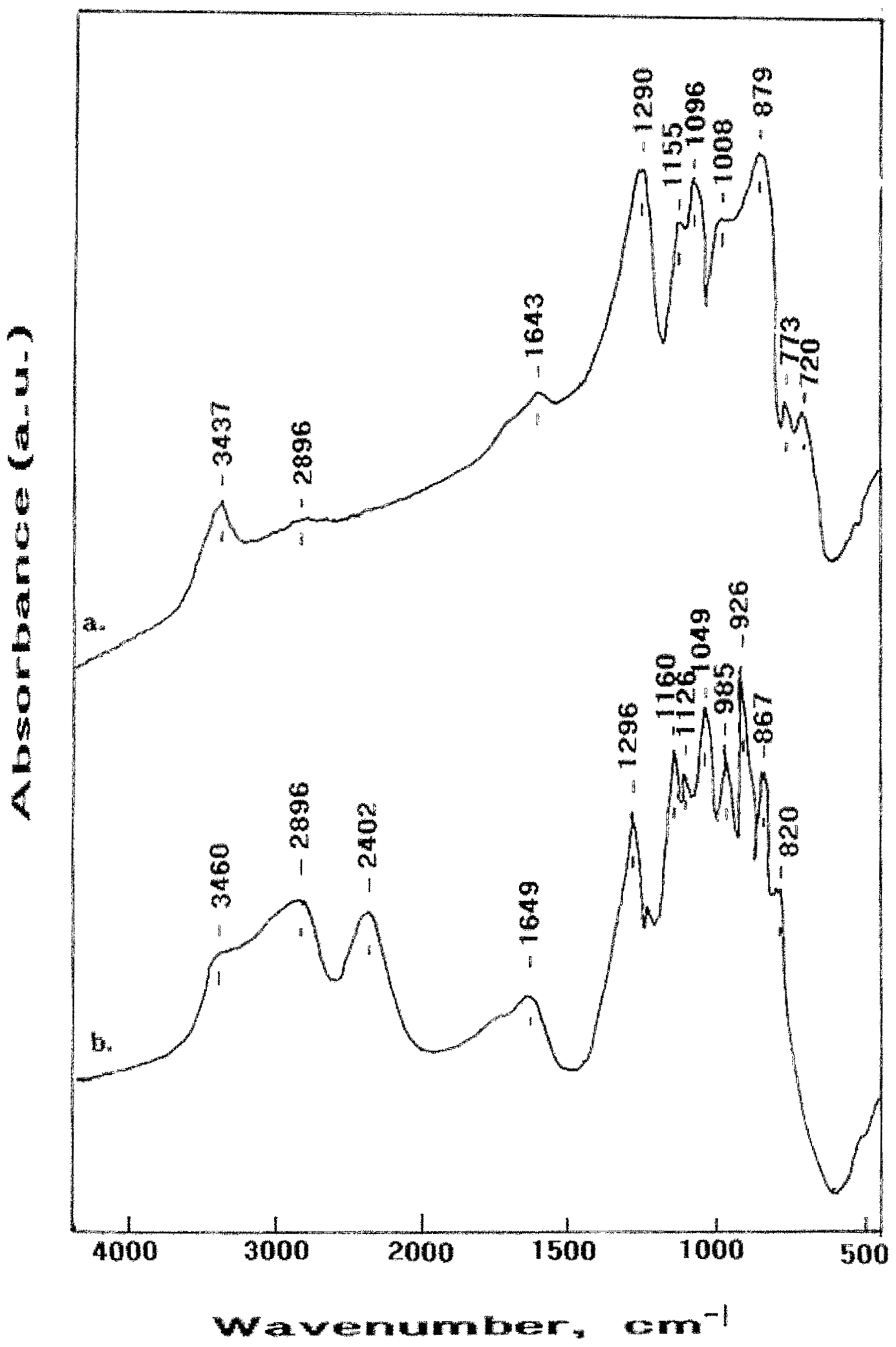

Figure 2. FT-IR spectra for (a) "as-received" $\mathrm{NaP}$ granular and (b) $\mathrm{NaP}$ solution after drying. 


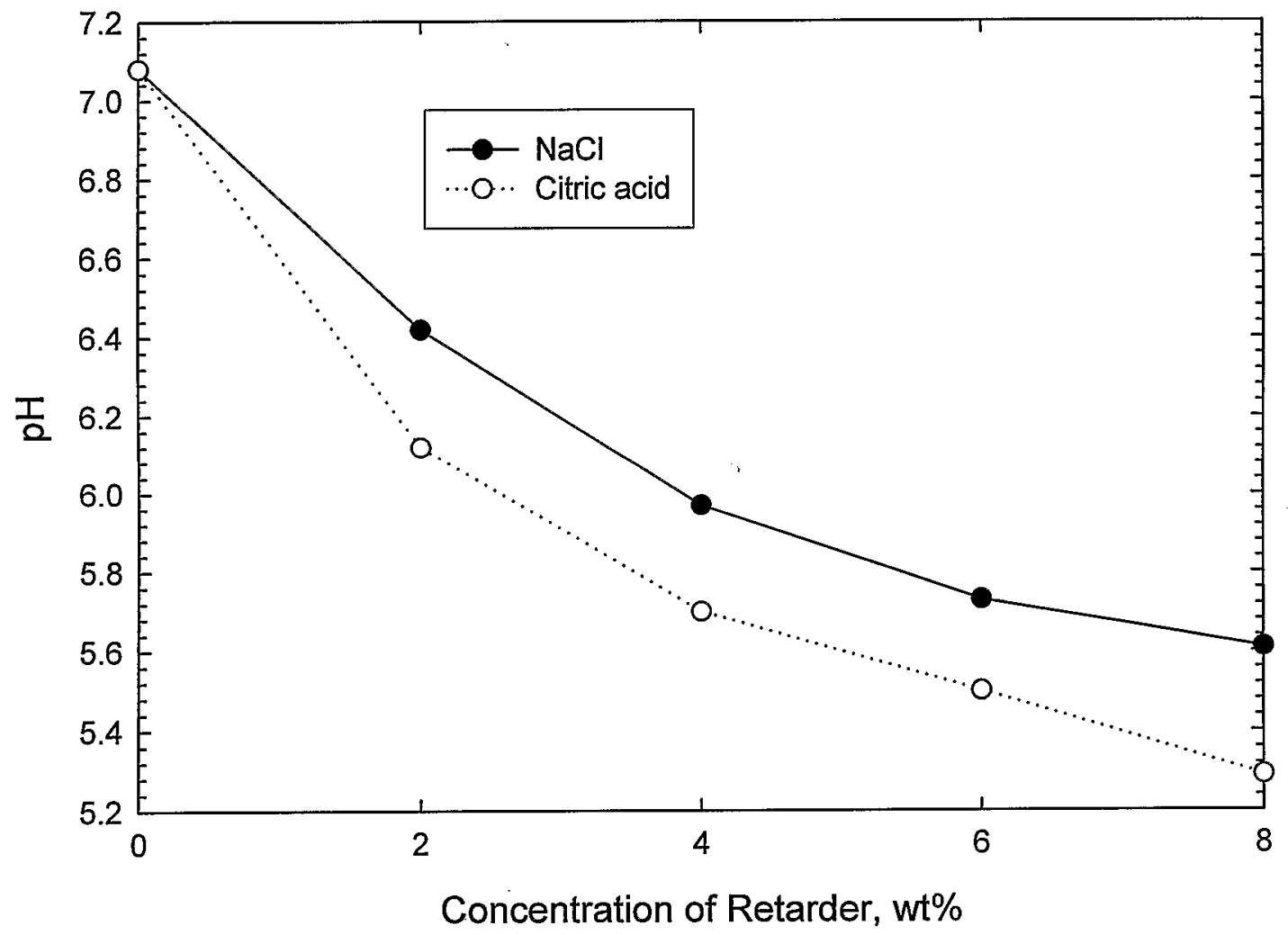

Figure 3. Changes in $\mathrm{pH}$ value of pore solution extracted from cement slurries as a function of retarder contnet. 


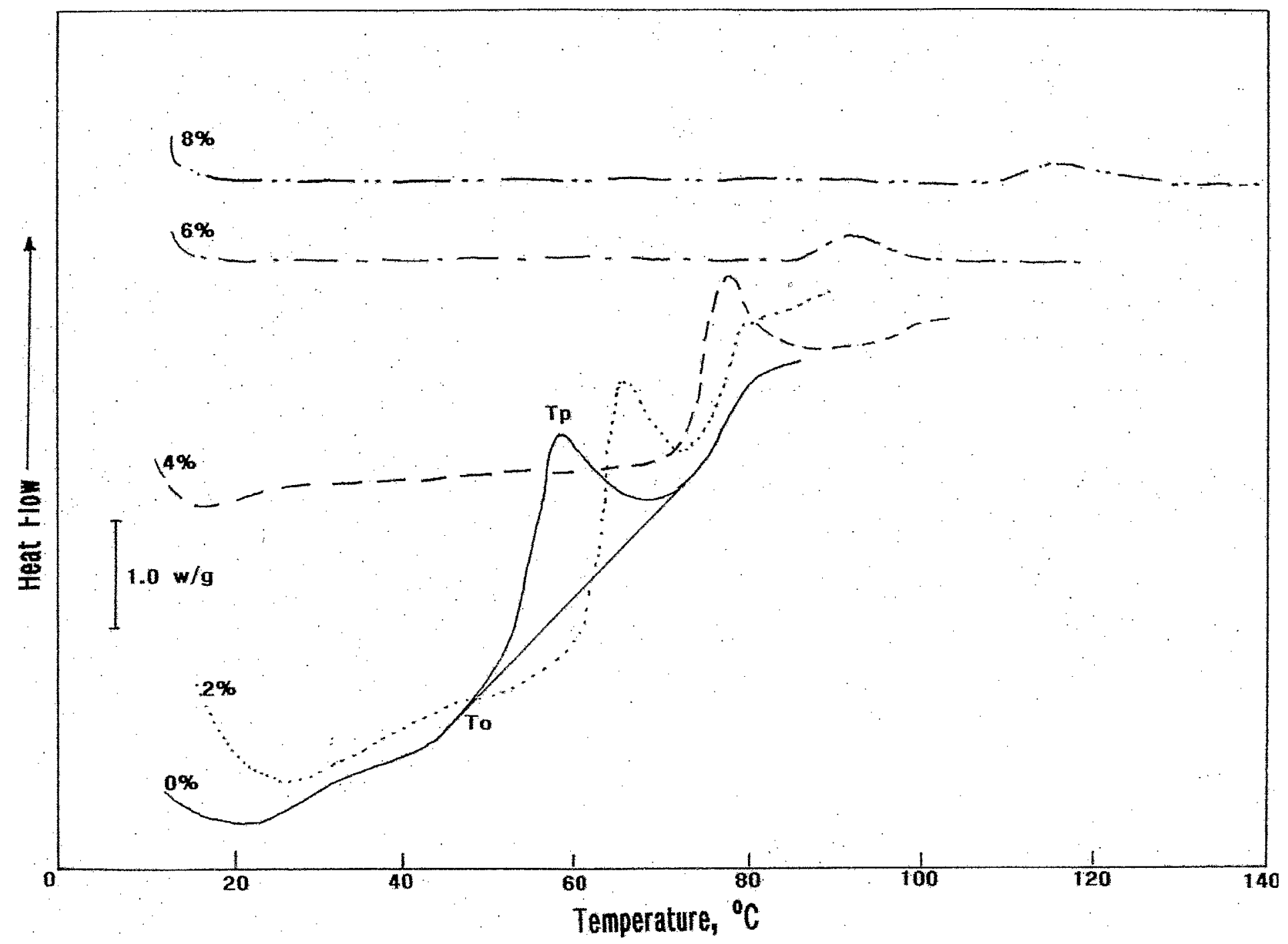

Figure 4. Non-isothermal DSC exothermic curves for NaCl-retarded and non-retarded cement slurries. 


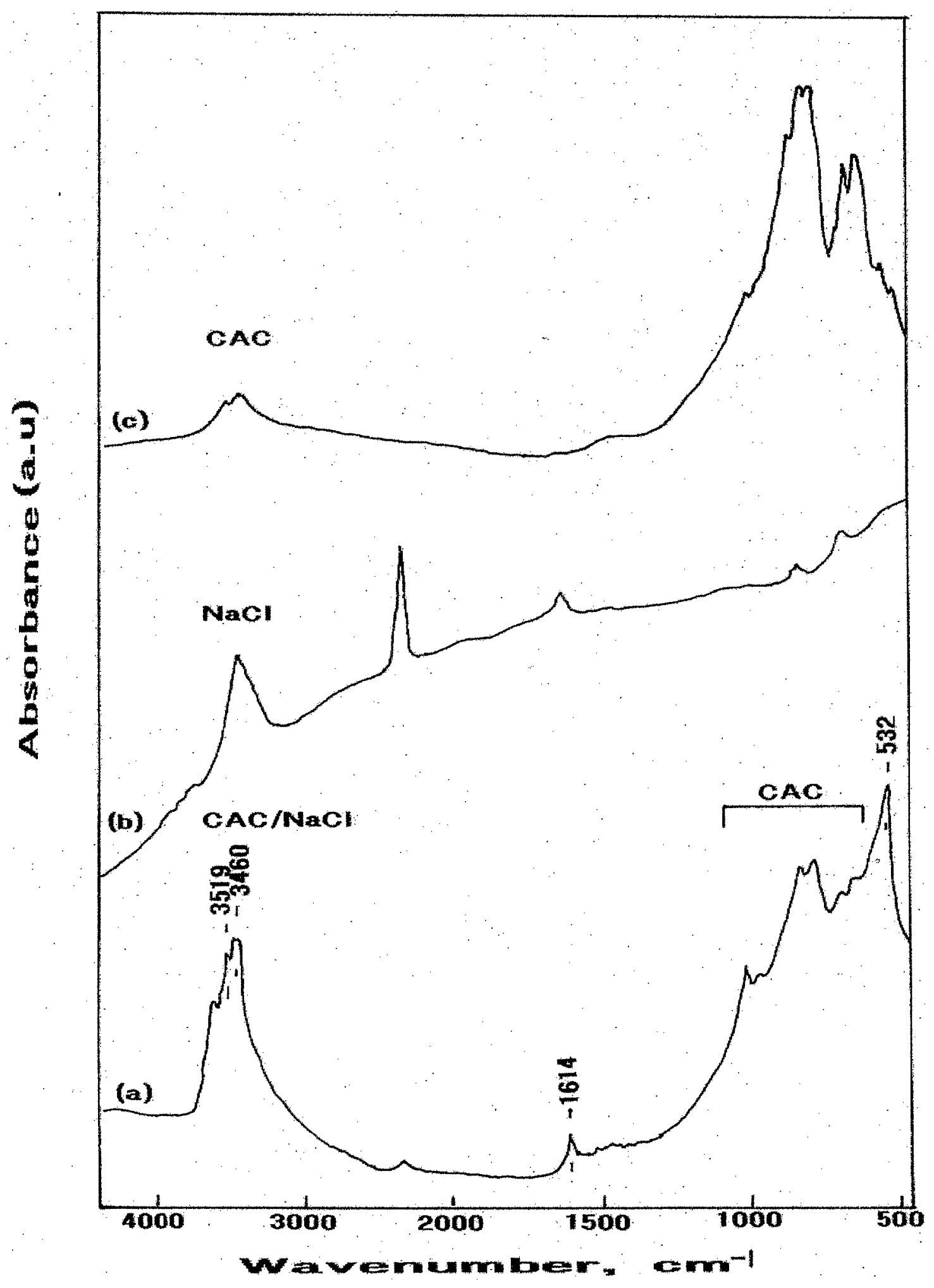

Figure 6. FT-IR spectra for (a) NaCl-modified CAC cement and two reference samples, (b) $\mathrm{NaCl}$, and (c) CAC. 


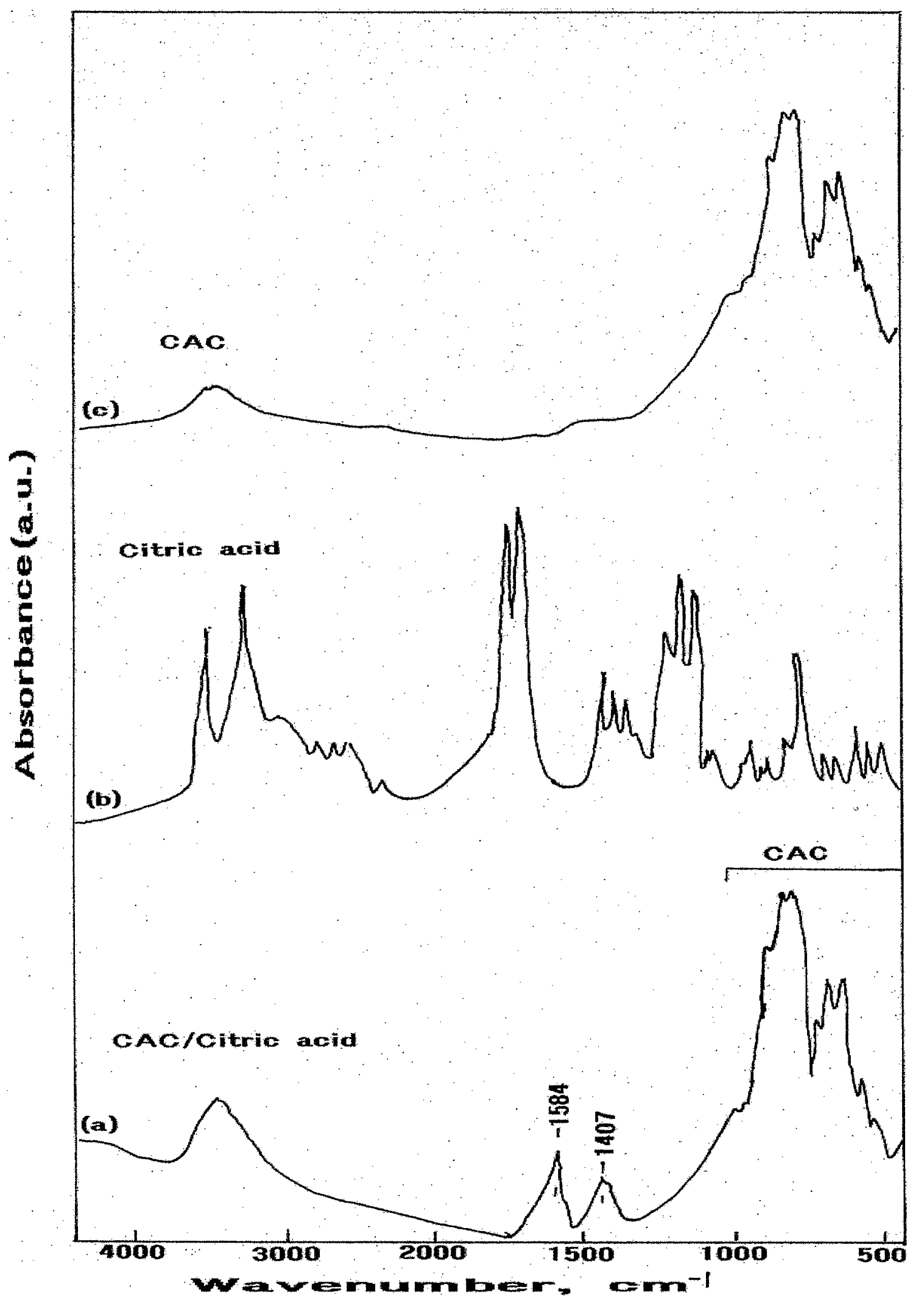

Figure 7. FT-IR spectra for (a) citric acid-modified CAC cement and two reference samples, (b) citric acid and (c) CAC. 


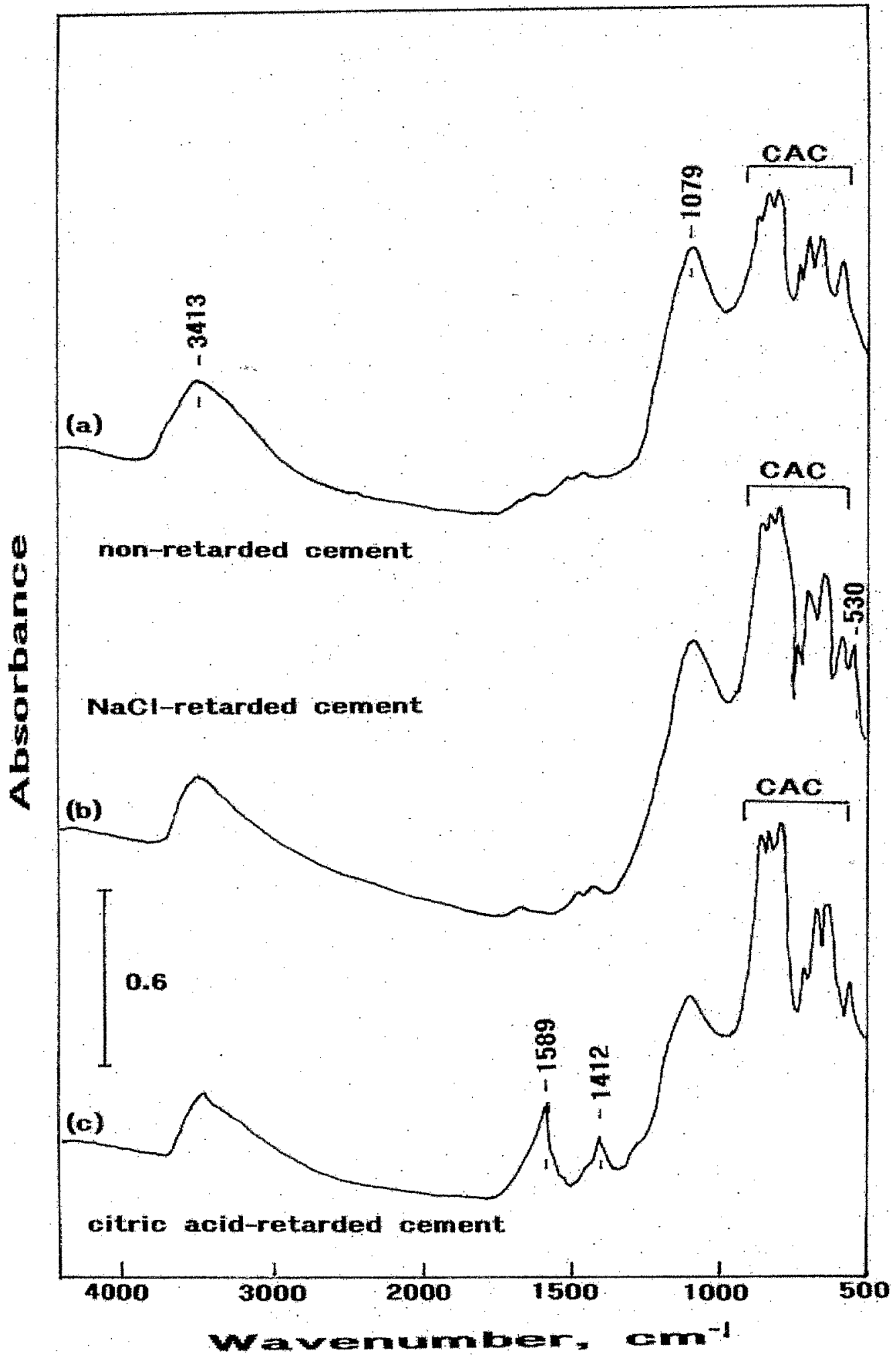

Figure 8. FT-IR spectra for (a) non-retarded CaP cement, (b) NaClretarded $\mathrm{CaP}$ cement, and (c) citric acid-retarded $\mathrm{CaP}$ cement cured at room temperature. 


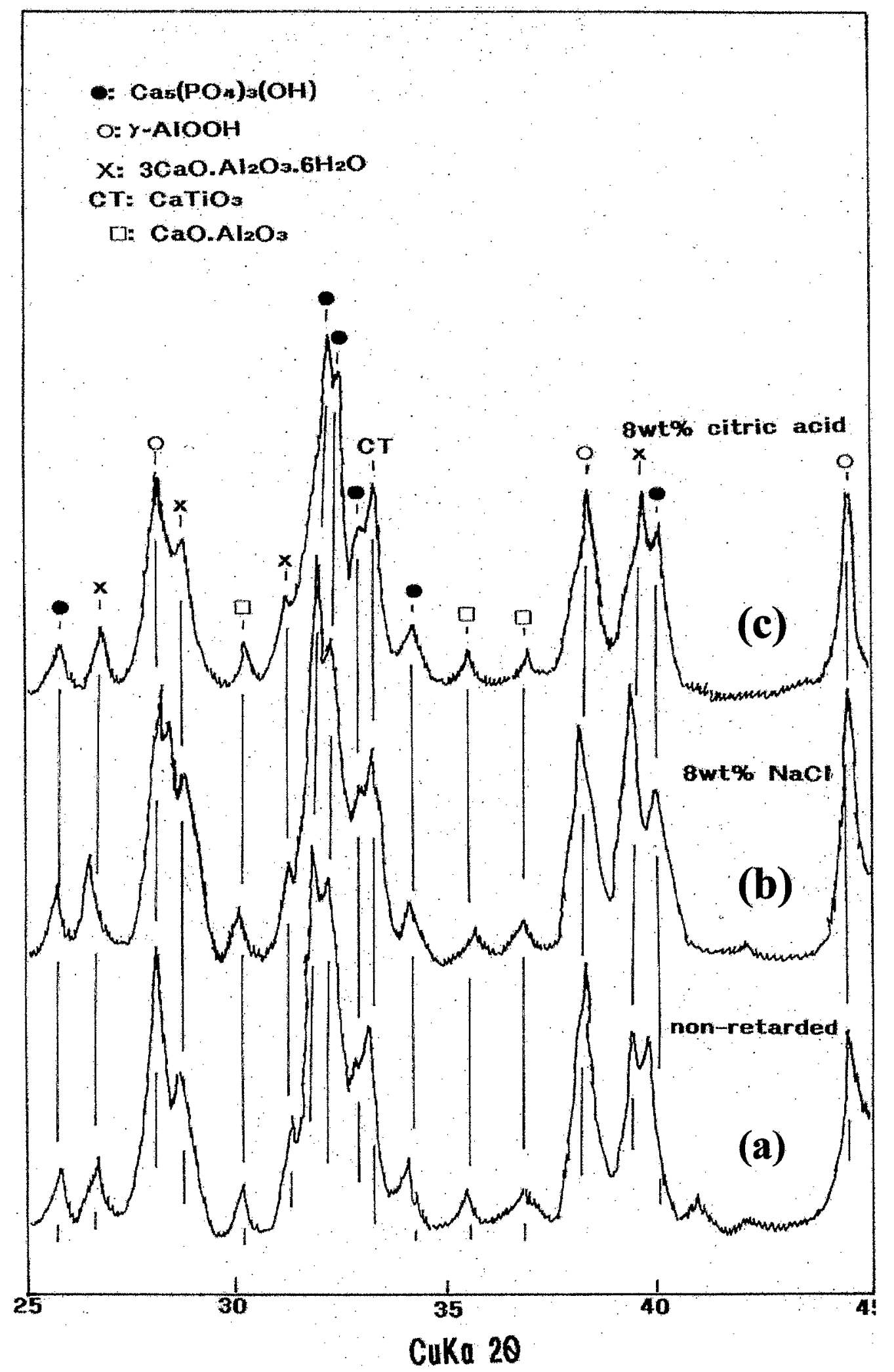

Figure 9. XRD tracings for (a) non-retarded cement, (b) $8 \mathrm{wt} \%$ $\mathrm{NaCl}$-retarded cement, and (c) $8 \mathrm{wt} \%$ citric acid-retarded cement after autoclave for 24 hours at $180^{\circ} \mathrm{C}$. 


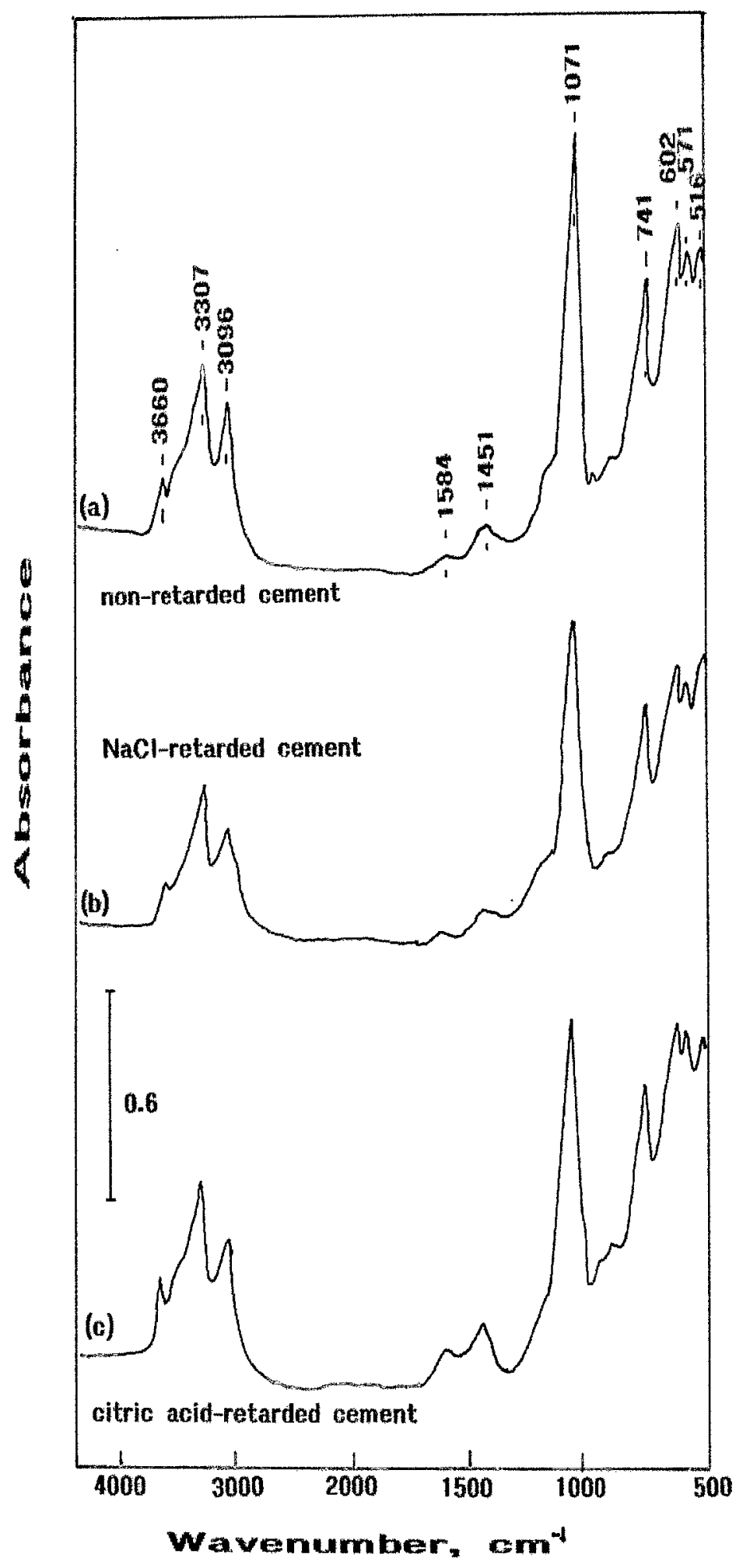

Figure 10. FT-IR spectra for (a) non-retarded cement, (b) $8 \mathrm{wt} \% \mathrm{NaCl}-$ retarded cement, and (c) $8 \mathrm{wt} \%$ citric acidretarded cement after autoclaving for 24 hours at $180^{\circ} \mathrm{C}$. 


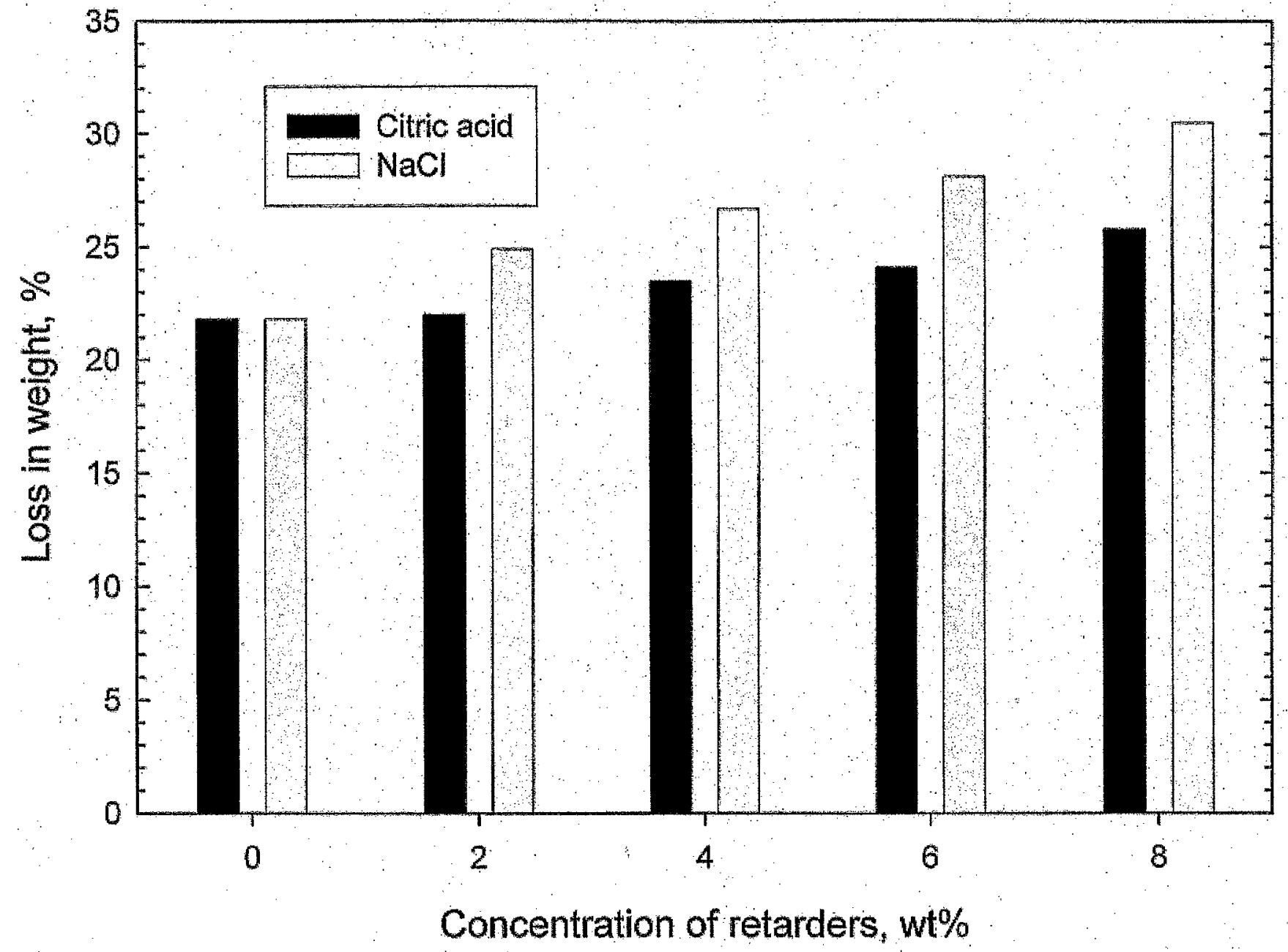

Figure 11. Loss in weight of retarded and non-retarded cements after exposure for 20 days in $\mathrm{CO}_{2}$-laden acid at $180^{\circ} \mathrm{C}$. 

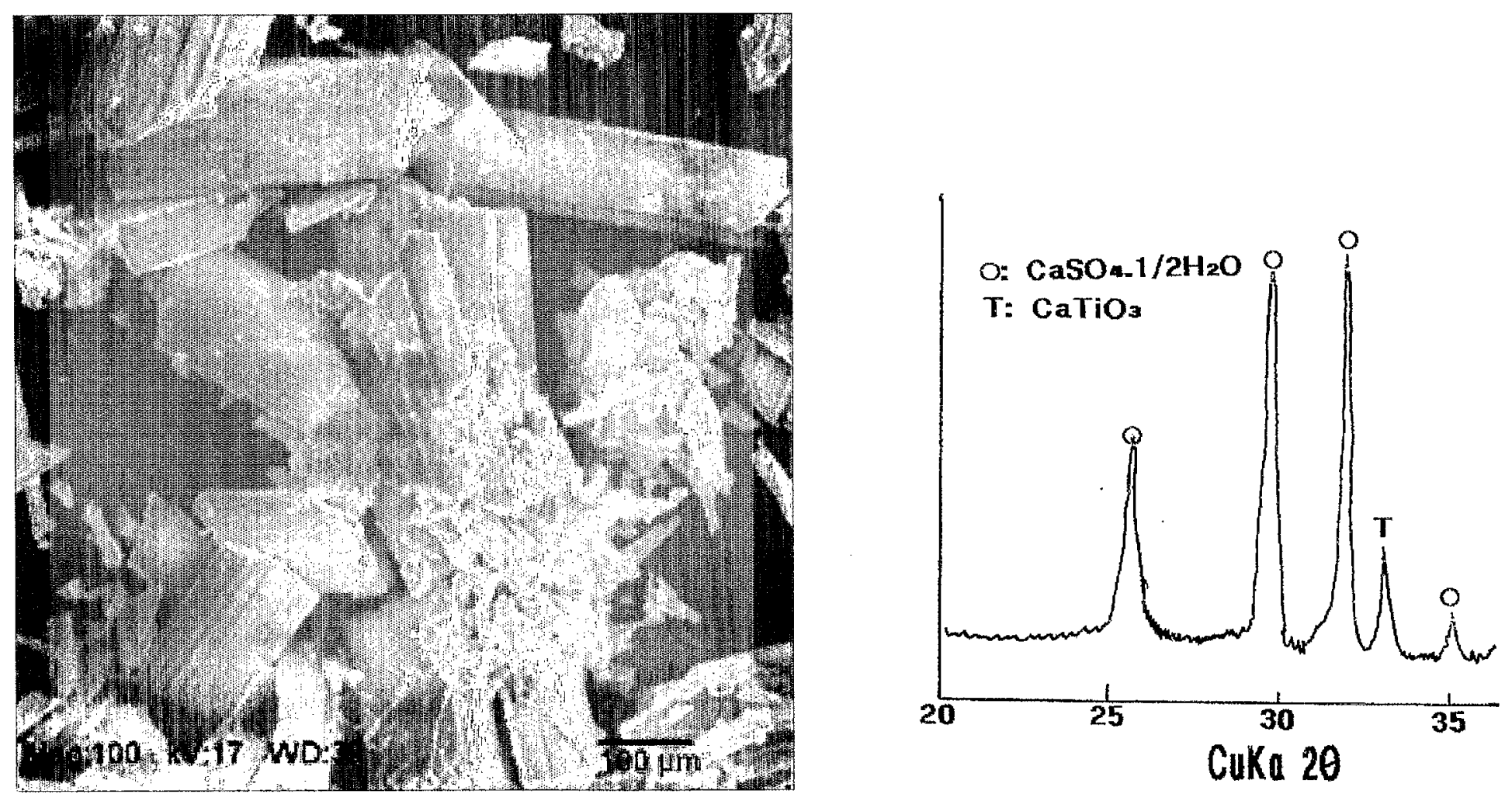

Figure 12. SEM image and XRD pattern of the acid corrosion products formed on unmodified cement's surfaces during the 20-day-long exposure. 


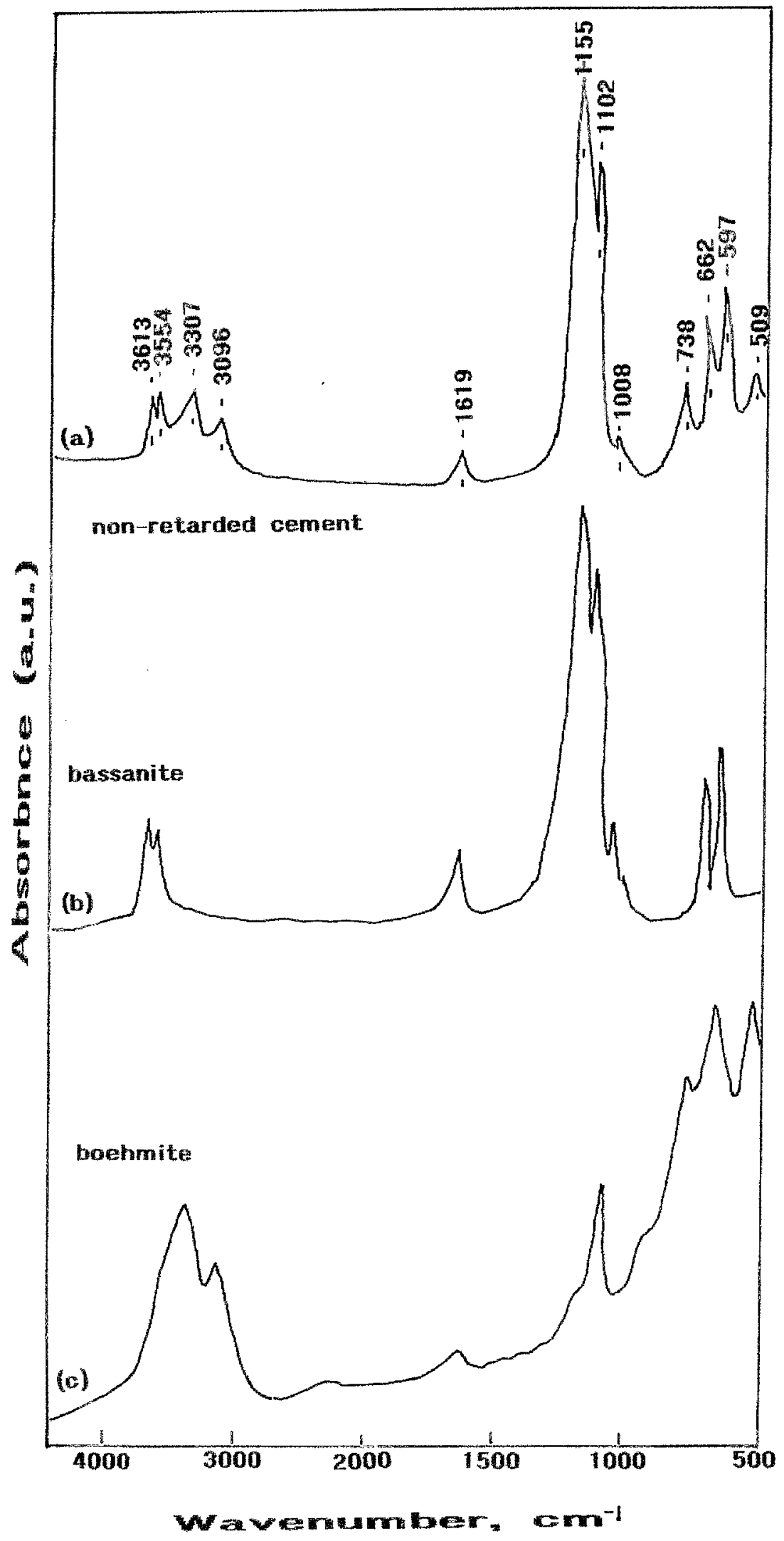

Figure 13. FT-IR spectra for (a) the sample removed from superficial layers of 20 day-exposed non-retarded cement and two reference samples, (b) bassanite and (c) boehmite. 